原 著

\title{
Resistance to Photodynamic Therapy in Murine Leukemia Cells In Vitro
}

\author{
Hideo KUMASAKA, Tetsuya OKUNAKA, Chimori KONAKA, \\ Katsuo AIZAWA and Harubumi KATO \\ First Department of Surgery and Department of Physiology, \\ TOKYO MEDICAL University \\ Nishishinjuku 6-7-1, Shinjuku-ku, Tokyo 160-0023, JAPAN \\ $+81-3-3342-6111$ (Ext. 5071)
}

\begin{abstract}
A photodynamic therapy (PDT)-resistant variant of the P388 murine leukemia cell line was isolated by repeated PDT with mono-L-aspartyl chlorin e6 (NPe 6) in vitro to the $0.1 \%$ survival level, followed by twelve regrowth cycles. The resistant variant was 1.38-fold more resistant to PDT with NPe $6(10 \sim 15 \mu \mathrm{g} / \mathrm{ml})$. However, more than $20 \mu \mathrm{g} / \mathrm{m} \ell$, there was no difference between cells. The PDT-12 cells had less uptake of NPe 6 after $2 \mathrm{~h}$ incubation than P388. We examined cross-resistance to adriamycin and the partitioning behavior determinant of the aqueous biphasic system. There was no difference in cytotoxicity and the uptake of adriamycin (ADM) between parental and PDT-12 cells. Partitioning behavior of parental cells and PDT-12 cells was compared. The latter has an inherently higher degree of membrane hydrophobicity. NPe 6 is comparatively hydrophilic, but the P388/ADR cells had reduced accumulation of the drug by extrusion by P-glycoprotein rather than membrane hydrophobicity. Furthermore, NPe 6-PDT cytotoxicity depended on accumulation into cells. Therefore, the PDT-12 cells acquired a hydrophobic membrane by repeating NPe 6-PDT twelve times. The PDT-12 cells were not cross-resistant to adriamycin. NPe 6 penetration into PDT-12cells was prevented by membrane hydrophobicity.

Key words : photodynamic therapy-resistance, P388 murine leukemia cells, NPe6, membrane hydrophobicity, extrusion by P-glycoprotein
\end{abstract}

\section{Introduction}

Photodynamic therapy (PDT), based on the photosensitizer Photofrin, is currently being applied in clinical trials for various solid tumors ${ }^{1-3)}$. The success of PDT stems from the fact that, by a yet undetermined mechanism, the photosensitizer is selectively retained in tumor rather than normal sur-

(平成11年1月26日受理, 平成11年3月16日揭載決定)

(Received January 26th 1999, Accepted March 16th 1999) 
rounding tissues, thus enabling differential cytotoxicity ". "The most commonly used sensitizers in PDT are hematoporphyrin derivatives ( $\mathrm{HpD}$ ) and commercially semipurified Photofrin. However, these compounds have some inherent drawbacks ${ }^{(j)}$. In recent years, new second generation photosensitizers have been developed, one class of which is mono-L-aspartyl chlorin e6 (NPe 6 ). while a cheaper diode laser system is commonly used as a light source in pain control, it is difficult to use the diode laser for PDT with commonly available photosensitizers, because its wavelength is too longer and the laser power is low. Katumi et al. developed a new high-power red laser diode system for PDT with $\mathrm{NPe} 6^{7,8)}$. The laser beam has relativery short wavelength (664 $\mathrm{nm})$ and relatively high power $(50-500 \mathrm{~mW} /$ cni2). Fibrosarcoma in mice was successfully treated with this system ${ }^{9}$. However, the mechanism of tumor destruction in vitro using NPe 6 has yet to be determined. We tried to isolate resistant cells to NPe 6-PDT as a tool in the clarification of PDT mechanisms.

\section{Materials and Method \\ Drugs}

NPe6 was obtained from Meiji Seika Kaisha Ltd., (Tokyo, Japan). NPe 6 is an effective photosensitizer with a major absorption band at $664 \mathrm{~nm}$, whose potential for PDT has been explored ${ }^{7.8)}$. Adriamycin (ADM) was obtained from Kyowa Hakkou Kogyo Co. Ltd. (Tokyo, Japan).

\section{Cells}

P388 murine leukemia and P388/ADR, a subline expressing the multi-drug resistance (MDR) phenotype. The P388 cells were used to isolate PDT-resistant variants and to serve as the parental strain in all experiments. The cells were grown in RPMI-1640 medium supplemented with $8 \%$ FCS, antibiotics and $2 \mathrm{ME}$.

\section{Isolation Procedure for PDT-resistant P388}

\section{Cell Strain}

The P 388 cells were subjected to a series of incubations with NPe 6 and light irradiation in order to obtain PDT-resistant strains.

The cells $\left(5 \times 10^{4}\right.$ cells $\left./ m \ell\right)$ were plated in 30-mm plastic Petri dishes, and NPe $6(25 \mu \mathrm{g} /$ $m l)$ was added to the plates. After incubation at $37^{\circ} \mathrm{C}$ for $4 \mathrm{~h}$, the drug medium was removed and the cells were rinsed with fresh growth medium, and then replaced in 30-min plastic Petri dishes. The dishes were exposed to a light fluence rate of $39 \mathrm{~mW} / \mathrm{cm}^{2}$ delivered at a fluence of $10 \mathrm{~J} / \mathrm{cni}^{2}$ ( $664 \mathrm{~nm}$ wavelength) in vitro to the $0.1 \%$ survival level, followed by regrowth for twelve cycles. The surviving strain was designated PDT-12.

\section{PDT Sensitivity}

Each cell type $\left(5 \times 10^{-1}\right.$ cells $\left./ m \ell\right)$ was plated in 24-well plates, and different doses of $\mathrm{NPe} 6$ $(0,10,15,20,25,30 \mu \mathrm{g} / \mathrm{m} \ell)$ were added to the plates. After incubation at $37^{\circ} \mathrm{C}$ for $2 \mathrm{~h}$ in the dark, the drug medium was removed and cells were rinsed with fresh growth medium and then replaced in 96 -well plates. The plates were exposed to light fluence rate of 39 $\mathrm{mW} / \mathrm{cm}^{2}$ delivered at a fluence of $10 \mathrm{~J} / \mathrm{cm}^{2}(664$ $\mathrm{nm}$ wavelength) and returned to a $37^{\circ} \mathrm{C}$ incubator. After incubation for $24 \mathrm{~h}$, the viability was determined by MTT [3-(4, 5-dimethy]thiazole-2-yl)-2, 5-diphenyltetrazolium bromide] assay.

\section{NPe 6 Uptake}

The cells $\left(5 \times 10^{7}\right.$ cells $)$ were plated in 100 mm plastic Petri dishes, and NPe $6(10,15,20$ 


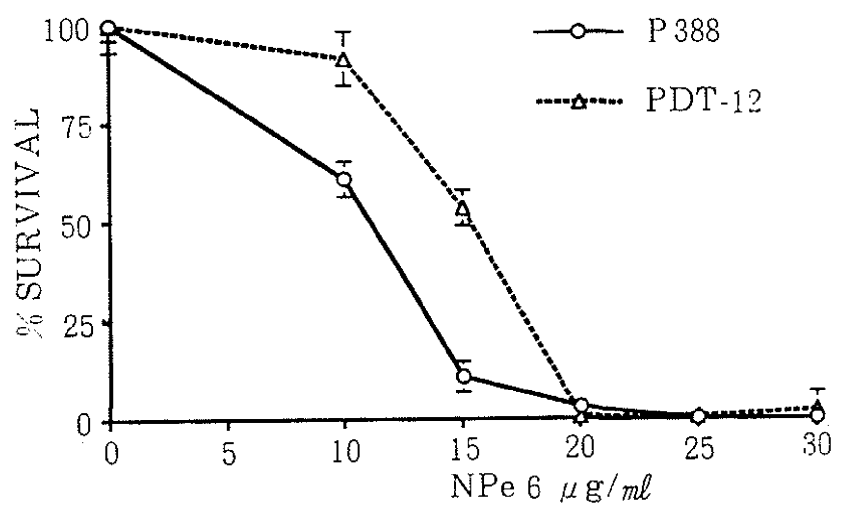

Figure 1 Survival curves for NPe6-PDT treatment of P388 and PDT-12 cells. Cells were incubated with $10,15,20,25$ or $30 \mu \mathrm{g} / \mathrm{ml}$ $\mathrm{NPe} 6$ for $2 \mathrm{~h}$ and exposed to $10 \mathrm{~J} / \mathrm{cm}$. Each point is the average of triplicate wells and error bars indicate the standard error

$\mu \mathrm{g} / \mathrm{ml}$ ) was added to the dishes and the cells were then incubated at $37^{\circ} \mathrm{C}$ for $2 \mathrm{~h}$. The drug medium was then removed and cells were rinsed with fresh growth medium twice. The samples were frozen/thawed and then lysing fluid, $0.7 \mathrm{~m} \ell$ methanol and $0.1 \mathrm{~m} \ell \quad 0.4 \%$ EDTA / 50mM HEPES ( $\mathrm{pH} 7.4$ ), was added. The lysates were mixed for $5 \mathrm{~min}$, and centrifuged at $1,200 \mathrm{rpm}$ for $5 \mathrm{~min}$. The supernatant was analyzed by high performance liquid chromatography (HPLC). The HPLC system consisted of a 5- $\mu \mathrm{m}$ silica column eluted with a mixture of 2 mM-TBA (tetra butyl ammonium)/ methanol ( $1: 3$, vol / vol). A HITA. CHI D-7500 integrator was used to analyze the chromatograms.

\section{Adriamycin Sensitivity}

The cells $\left(4 \times 10^{3}\right.$ cells $\left./ \mathrm{m} \ell\right)$ were plated in 96 -well plates and incubated for $24 \mathrm{~h}$, and then exposed to adriamycin $(0.001 \sim 0.1 \mu \mathrm{g} / \mathrm{m} \ell)$. After 3 days, the sensitivity of cells to adriamycin was determined by MTT assay.

\section{Adriamycin Uptake}

The cells $\left(5 \times 10^{7}\right.$ cells $)$ were plated in 100 mn plastic dishes, and adriamycin $(1 \mu \mathrm{g} / \mathrm{m} \ell)$ was added and cells were then incubated for
100 or $200 \mathrm{~min}$. The appropriate samples were frozen / thawed and lysing fluid was mixed with $5 \mathrm{~m} \ell$ ethylacetate / propanol $(4: 1)$ and added, and the samples were shaken for $20 \mathrm{~min}$. The cell lysates were centrifuged at 3, $500 \mathrm{rpm}$ for $10 \mathrm{~min}$, and the supernatant was evaporated. The extracts were dissolved in $250 \mu 1 \mathrm{H}_{2} \mathrm{O} /$ methanol (1:1), and centrifuged at $1,500 \mathrm{rpm}$ for $10 \mathrm{~min}$. The upper solution was loaded on an HPLC'(1)

\section{Partitioning of P388 \& PDT-12}

Partition coefficients of cells between the phases of aqueous polymer mixtures were measured as follows : 5\% (w/ v) dextran T500 (Mr 500,000; lot 243862 Pharmacia, Uppsala) and $4 \%$ poly ethylene glycol (PEG) (Mr 6000 ; Wako Pure Chemical Industries, Ltd., Osaka, Japan) were prepared in Dulbecco's phosphate buffered saline (lot No. 3201885 ; Gibco, Paisley). After thorough mixing, the phases were separated by centrifugation at $3,000 \mathrm{rpm}$ for $20 \mathrm{~min}$. at $22^{\circ} \mathrm{C}$. The $2.5 \mathrm{~m} \ell$ lower phase and $2.5 \mathrm{~m} \ell$ upper phase were mixed with the appropriate concentration of palmitine $(0.00006 \sim 0.0002 \%)$. This mixture was added to a suspension of $10^{6}$ cells in 100 $\mu \mathrm{l}$ isotonic $\mathrm{NaCl}$. Immediately after mixing, a $0.2 \mathrm{ml}$ sample was removed for determination of cell concentration. At timed intervals thereafter, $0.2 \mathrm{ml}$ portions were taken from the center of the upper phase for cell counting'").

\section{Results}

\section{PDT Cytotoxicity}

Figure 1 shows PDT survival curves for the P388 parental cell line and the PDT-resistant variant cell line following $2 \mathrm{~h}$ incubation with NPe 6. PDT-12 was approximately 1.38-fold more resistant to PDT as $50 \%$ survival frac- 


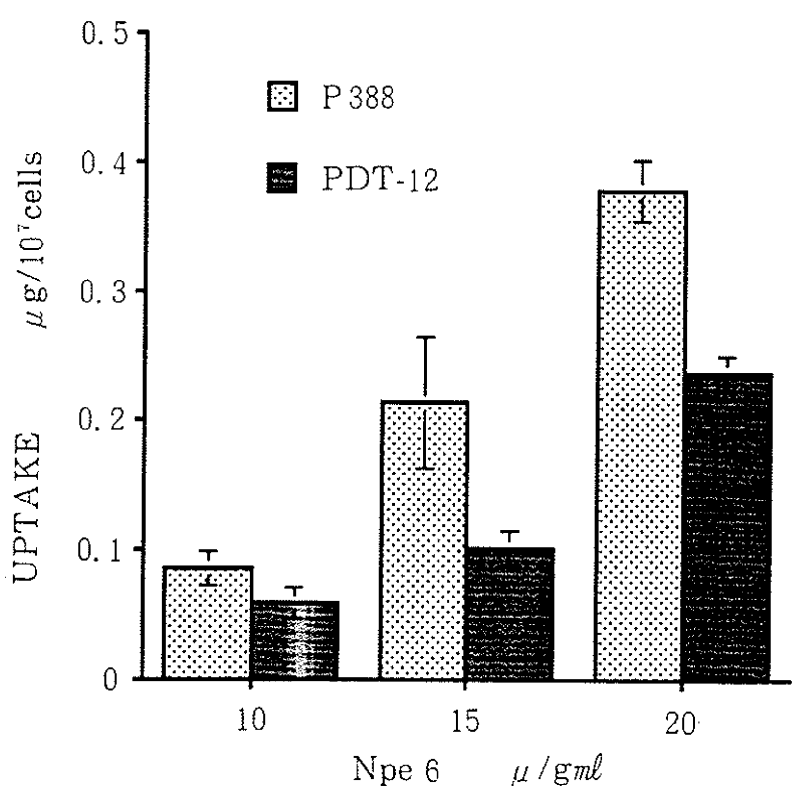

Figure 2 NPe 6 uptake per $10^{7}$ cells in P388 and PDT- 12 cells at $2 \mathrm{~h}$ incubation determined by HPLC. Three independent experiments were conducted with each cell type and the error bars indicate the resulting standard error

tion $(\mathrm{P}<0.01)$. However, at more then $20 \mu \mathrm{g}$ $/ m \ell$, there was no difference between the cell lines. In order to test the reproducibility of these results, PDT survival experiments were carried out with P388 \& PDT-12 cells run under identical conditions three times.

\section{NPe 6 Uptake}

Comparisons of relative NPe 6 uptake between P388 and PDT-12 are shown in Fig. 2. The uptake by PDT-12 was less than that of parental P388 at various concentrations. A significant difference was observed between P388 and PDT-12; NPe 6 uptake ratio, P388 / PDT-12 were $1.46 \pm 0.018$ at $10 \mu \mathrm{g} / \mathrm{m \ell}, 2.11$ \pm 0.079 at $15 \mu \mathrm{g} / \mathrm{ml}$ and $1.60 \pm 0.099$ at $20 \mu \mathrm{g} /$ $m \ell$ of the accumulation of NPe 6.

\section{Adriamycin Sensitivity}

The survival curves of PDT with NPe 6 for P388, P388/ADR and PDT-12 are shown in Fig. 3. The P388/ADR cells showed a high degree of resistance to adriamycin, as ex-

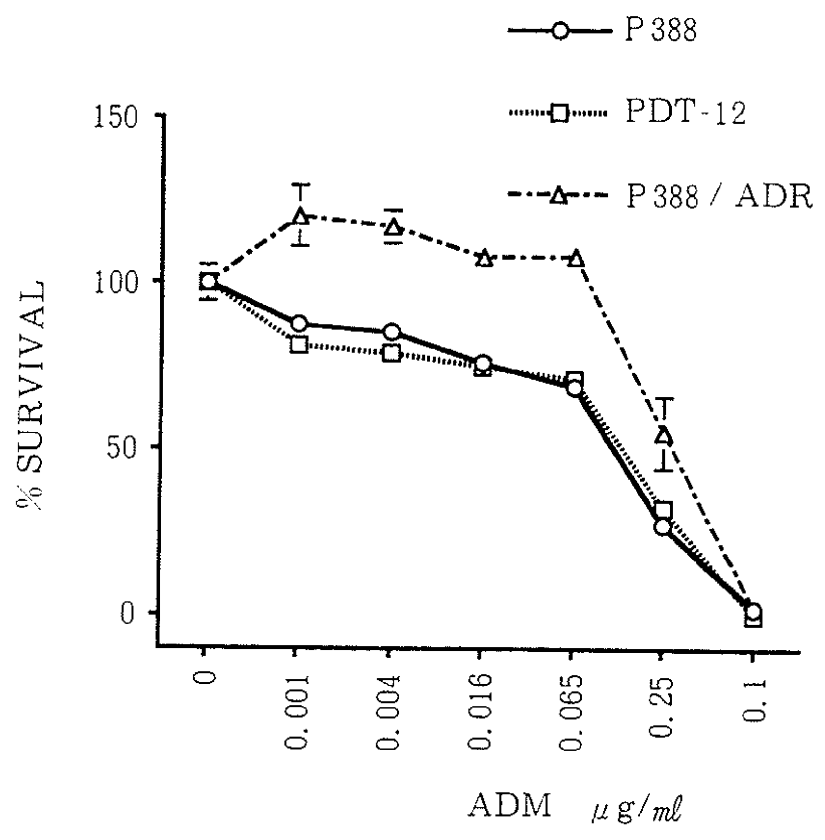

Figure 3 Survival curves for adriamycin sensitivity of P388, P388 / ADR and PDT-12 cells. Cells were incubated with $0.001 \sim 0.1 \mu \mathrm{g} /$ $m \ell$ adriamycin. Each point is the average of triplicate wells and error bars indicate the standard error

pected. There was, however, no significant difference in adriamycin sensitivity between P388 and PDT-12 cells.

\section{Adriamycin Uptake}

The uptake of the various adriamycin fractions in each cell line is shown in Fig. 4. The adriamycin uptake of P388/ADR was less than that of the other cell lines at various concentrations. However, no significant difference was observed between P388 and PDT-12.

\section{Partitioning of P388 \& PDT-12}

In the absence of palmitine, cells rapidly dropped to the interface of the complete partitioning system, and addition of palmitine promoted the partitioning of cells into the upper phase as shown in Table 1. With P388 cells, a partition ratio of 50 was achieved after $20 \mathrm{~min}$, using $0.0001 \%$ (w/ v) palmitine. The PDT-12 cells needed $0.0002 \%$ of palmitine. With each cell line, more than 90 


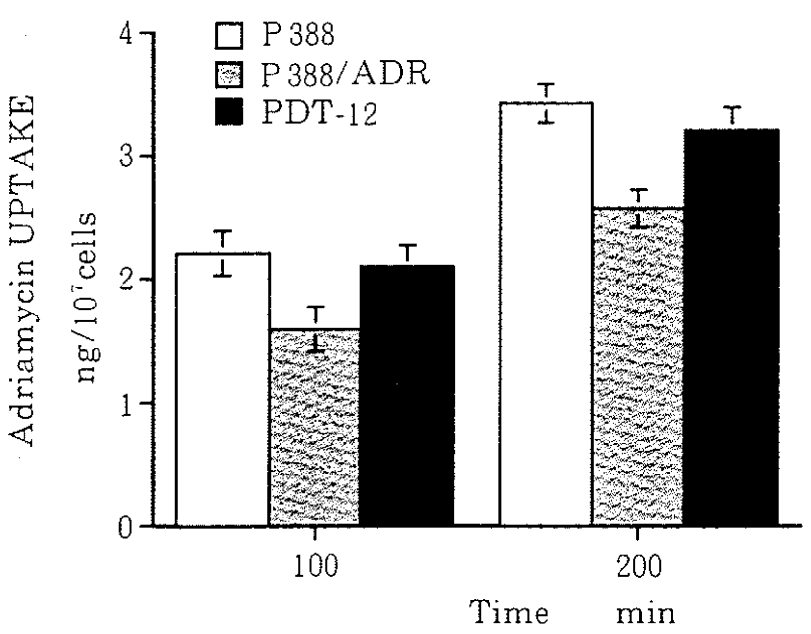

Figure 4 Adriamycin uptake per $5 \times 10^{7}$ cells in P388, P388/ADR and PDT-12 for 100 or $200 \mathrm{~min}$. incubation determined by HPLC. Three independent experiments were conducted with each cell type and the error bars indicate the resulting standard error

$\%$ of the cells could be brought into the upper phase by addition of sufficient palmitine. The PDT-12 cells required approximately 2fold more of either ester than did P388 to achieve this result.

\section{Discussion}

The primary goal of this study was to derive NPe 6-PDT-resistant P388 cells for future use as a tool in the study of PDT mechanisms of action in vitro and in vivo. Isolation of drug-resistant cell lines has produced models for subsequent biochemical and molecular studies relating to drug acton, drug resistance, and cross-resistance "2). This has been achieved, but the degree of resistance is not high, so work on further enhancing the resistance is in progress. PDT is a particular technique which utilizes a photosensitizer and laser. Few systematic studies of cellular resistance to photodynamic therapy have been reported to date. The mechanisms of resistance to PDT can be divided into two categories : intercellular
Table 1 Partitioning behavior of P388 and PDT-12 cells

\begin{tabular}{c|cc}
\hline Parmitine $\%$ & P388 & PDT-12 \\
\hline 0.00006 & 45 & 28 \\
0.0001 & 52 & 40 \\
0.0002 & 78 & 67 \\
\hline
\end{tabular}

Cells were partitioned for $20 \mathrm{~min}$. Numbers represent percentage of total cells bound in upper phase. The partition ratio of $50 \%$ was achieved, the P388 cells needed $0.0001 \%$ palmitine and PDT-12 cells needed $0.0002 \%$ palmitine

accumulation of photosensitizers, and others. Singh et al. isolated Photofrin-PDT-resistant cells (RIF-8), which were obtained by repea ted photof rin incubation and light treatment of mouse radiation-induced fibrosarcoma (RIF) cells"). RIF-8 cells did not show reduced Photofrin uptake ${ }^{9.13)}$, and were thus classified in the latter category. Mitchell et al. also observed a degree of porphyrinPDT resistance and impaired porphyrin accumulation in CHO-MDR cells ${ }^{11)}$. The resistance to $\mathrm{PDT}$ of $\mathrm{CHO}-\mathrm{MDR}$ and human breast carcinoma cells (MCF-7) was associated with decreased intracellular concentration of Photofrin ${ }^{1,15)}$. These cell lines thus seem to belong to the former category. PDT12, obtained by repeated NPe 6-PDT and regrowth for twelve cycles reduced NPe 6 uptake (Fig. 2). NPe 6 uptake ratio between P388 and PDT-12 was $2.11 \pm 0.079$ at $15 \mu \mathrm{g} /$ $m \ell$. Further, NPe 6-PDT sensitivity was dependent on the accumulation of NPe 6 in our preliminary work. Therefore, PDT-12 cells seem to belong to the former category. This implies that the involved mechanisms differed from those in Photofrin-PDT resistant RIF-8, but are similar to those in CHO-MDR and human breast carcinoma cells (MCF7). The observation was consistent with the finding that $\mathrm{P}$-glycoprotein is at least partly 
effective in altering $\mathrm{NPe} 6$ transportation. As regards chemotoxic cross-resistance in PDT-resistance cells, Singh et al. reported that RIF-8 cells were not cross-resistant to adriamycin and found no difference in the uptake of adriamycin between parental cells and RIF-8 cells ${ }^{93}$. Roger et al. reported that RIF-8 cells were cross-resistant to cispla$\operatorname{tin}^{16)}$. In contrast, in multi-drug-resistant (MDR) cell lines, Giannotti et al. reported no difference in sensitivity to PDT with sulfonated aluminum phthalocyanine between parental and MDR human erythroleukemic cells $^{17}$, while Marchesini et al. found 1.4fold higher Photofrin resistance under specific treatment conditions in adriamycin-resistant human MCF-7 cells's). P388/ADR, a subline of P388 murine leukemia selected for anthracycline resistance, exhibits a broad cross-resistance pattern and an enhanced outward drug transport system characteristic of the MDR phenotype ${ }^{18-20)}$. If there had been $\mathrm{P}$-glycoprotein amplification in the PDT -12 cells, one would expect PDT-12 cells to be less adriamycin sensitized than P388 cells (Figs. 3 and 4). However, we found no difference in adriamycin uptake and cytotoxicity. We speculated that PDT-12 cells differ in the ir expression of P-glycoprotein from parental cells. The possibility that reduced photosensitizer is the cause of membrane hydrophobicity has been examined by comparing the partitioning behavior of P388 and PDT12 , as a complementary approach to the study of NPe 6-PDT resistance. Gerson summarized data relating partitioning behavior in uncharged systems to membrane hydrophobicity, and provided information on the relationship between surface energy of cells and partitioning behavior ${ }^{21}$. Kessel compa- red the partitioning behavior of $\mathrm{P} 388$ to that of P388/ADR '1'. P388/ADR had an inherently higher degree of hydrophobicity due to membrane glycosylation. An enhanced level of cell - surface glycoprotein is associated with development of resistance to natural product $^{10)}$. We also found that NPe6-PDTresistant cells inherently had a 2 -fold higher degree of hydrophobicity (Table 1). NPe6 is comparatively hydrophilic. PDT-12 cells showed reduced accumulation of NPe6, because of the barrier of membrane hydrophobicity other than P-glycoprotein, and enhanced outward transport. These findings suggest the possibility of membrane changes that decreased the cellular concentration of NPe 6. Marchesini et al. found 1.4-fold higher Photofrin resistance under specific treatment conditions in MCF- 7 cells ${ }^{15}$. Similarly, PDT-12 showed approximately 1.38-fold higher resistance to PDT than parental cells at 10 to $15 \mu \mathrm{g} / \mathrm{m} \ell$ NPe6 (Fig. 1). However, the degree of resistance was not high, and at more than $20 \mu \mathrm{g} / \mathrm{m} \ell$, there was no difference between the cell lines, because the intracellular concentration reached a fatal dose under fixed fluence of $10 \mathrm{~J} / \mathrm{cm}^{2}$.

In conclusion, we have demonstrated that resistance to NPe 6-PDT can be achieved in vitro. PDT-12 cells acquired a hydrophobic membrane by repeating NPe 6-PDT twelve times. No researches has isolated PDTresistant cells showing reduced intercellular accumulation of photosensitizers. The PDT12 cells were not cross-resistant to the chemotherapeutic agent adriamycin. Furthermore, NPe 6 did not penetrate into PDT-12 cells due to the barrier of membrane hydrophobicity, rather than the cxtrusion by $\mathrm{P}$-glycoprotein. 


\section{References}

1) Marcus, S. L.: Photodynamic therapy of human cancer. Proc. SPIE., IS6, 5-56 (1990).

2) Dougherty, T. J.: In "Medical Radiology Innovations in Radiation Oncology," ed. Withers, H. R. and Peters, L. J. pp. 175-188 (1988) Springer-Verlag, Berlin.

3 ) Dougherty, T. J., Potter, W. R. and Bellnnier, D.: Photodynamic therapy for the treatment of cancer: current status and advances. In "Photodynamic Therapy of Neoplastic Disease,"ed. Kessel D. 1. pp. 1-20 (1990) CRC Press, Boca Raton, FL.

4) Lipson, R. L., Baldes, E. J. and Olsen, A. M.: The use of derivatives of hematoporyphyrin in tumor detection. J. Natl. Cancer Inst., 26, 1-5 (1961).

5 ) Doughherty, T. J., Potter, W. R. and Weishanpt, K. R.: The structure of the active component of hematoporphyrin derivative. In "Porphyrin Localization and Treatment of Tumor. s," ed. D. R. Doiron and C. J. Gomer. pp. 301 -310 (1984) Alan Liss, New York.

6) Razime, N., Balchum, O. J., Profio, A. F. and Carstens, E.: Skin photosensitivity : duration and intensity following intravenous $\mathrm{Hpd}$ and DHE. Photochem. Photobiol., 46, 925-928 (1987).

7 ) Katumi, T., Aizawa, K., Kuroiwa, Y., Saito, K., Kurata, Y., Ii, Y., Okunaka, T., Konaka, C. and Kato, H.: Photodynamic therapy with a diode laser for implanted fibrosarcoma in mice employing mono-L-aspartyl chlorin e6. Photochem. Photobiol., 64, 671-675 (1996).

8 Katumi, T., Aizawa, K., Okunaka, T., Kuroiwa, Y., Ii, Y., Saito, K., Konaka, C. and Kato, H.: Photodynamic therapy using a diode laser with mono-L-aspartyl chlorin e6 for implanted fibrosarcoma in mice. Jpn. J. Cancer Res., 85, 1165-1170 (1994).

9 ) Singh, G., Wilson, B. C., Sharkey, S. M., Browman, G. P., Dechamps, P.: Resistance to photodynamic therapy in radiation induced fibrosarcoma-1 and Chinese hamster ovarymulti-drug resistant cells in vitro. Photochem. Photobiol., 54, 307-312 (1991).

10) Ishida, H., Okabe, M., Gomi, K., Kitaura, K. and Satoh, M.: Comparison of intercellular concentration and cell growth inhibitory activity of doxorubicin, epirubicin and 4'-O-tetrahydro- pyranyldoxorubicin in human bladder carcinoma T24 and normal bladder HCV-29 cells. Cell. Phormacol., 2, 121-126 (1995).

11) Kessel, D.: Some determinants of partitioning behavior of lymphoblasts in aqueous biphasic system. Biochim. Biophys. Acta., 678, 245-249 (1981).

12) Kessel, D. and Erickson, C.: Porphyrin photosensitization of multi-drug resistant cell types. Photochem. Photobiol., 55, 397-399 (1992).

13) Luna, M. C. and Gomer, C. J.: Isolation and initial characterization of mouse tumor cells resistant to porphyrin-mediated photodynamic therapy. Cancer. Res., 51, 4243-42 (1991).

14) Mitchell, J. B., Glatstein, E., Cowan, K. H. and Russo, A.: Photodynamic therapy of multi -drug resistant cell lines. Proc. A. A. C. R., 29, 315 (1988).

15) Marchesini, R., Gritti, A., Colombo, A., Dasdia, T. and Sichirollo, A. E.: Effectiveness of photodynamic therapy after Photofrin II sensitization in a multi-drug resistant human breast carcinoma line in vitro. 3rd Biennial Meeting of the International Photodynamic Association (1990) Buffalo, New York.

16) Moorehead, R., Armstrong, S., Wilson, B. C., and Singh, G.: Cross-resistance to cisplatin in cells resistant to Photofrin-mediated photodynamic therapy. Cancer Res., 54, 2556-2559 (1994).

17) Giannotti, C., Andriamanpandry, A. and Werner, G. H.: Studies on resistance of human cancer cells to photosensitizing phthalocyanines. 3rd Biennial Meeting of the International Photodynamic Association (1990) Buffalo, New York.

18) Johnson, R. K., Chitnis, M. P., Embrey, W. M. and Gregory, E. B.: In vitro characteristics of resistance and cross-resistance of an adriamycin-resistant sub-line of P388 murine leukemia. Cancer Treat. Rep., 62, 1535-1547 (1982).

19) Inaba, M., Kobayashi, H., Sakurai, Y. and Johnson, R. K.: Active efflux of daunorubicin and adriamycin in sensitive and resistant sublines of P388 murine leukemia. Cancer Res., 39, 2200-2203 (1979).

20) Ling, V. and Gerlach, J.: Multidrug resistance. Breast Cancer Res. Treat., 4, 89-94 (1985).

21) Schurch, S. Gerson, D. F.: Determination of 
Cell / Medium interfacial tensions from contact angles in aqueous polymer systems. Biochim. Biophys. Acta., 640, 557-571 (1981). 